\title{
Gender performance in an out-of-school science context
}

\author{
Eva Silfver ${ }^{1}$ (D)
}

Received: 8 April 2016/Accepted: 19 October 2017/Published online: 12 March 2018

(C) The Author(s) 2018. This article is an open access publication

\begin{abstract}
This article examines how school students perform gender during a visit to a science centre where they programme Lego cars. The focus is on how students relate to each other-how they talk and what they do. Theoretically, the article draws on the 'heterosexual matrix' and a Foucauldian understanding of how power and knowledge are tightly interwoven and that discursive practices regulate people's possible positions and ways of being in different situations and contexts. The analysis is primarily based on video data from the science centre and a number of student interviews. The article gives several examples of how stereotypical gender performances are maintained but also challenged. This is important knowledge, because if we want to challenge norms, we first need to see them and understand how they are reproduced.
\end{abstract}

Keywords Science centre · Programming - Gender performances · Power relations

In this article, I present and analyse data from a grade eight class (twenty 14- to 15-yearold students) visiting a science centre where they worked with programming as part of their ordinary technology class. In Sweden, teachers' knowledge in programming is often low (Skolverket 2016), and visiting a science centre which offers basic programming to their students is therefore valuable. Technology is also an intrinsically interesting subject of study not least due to its inconsistencies with respect to status. For instance, technology comes with different discursive meanings depending on whether it concerns technology at

Lead Editor: A. Hussénius.

Eva Silfver

eva.silfver@umu.se

1 Department of Education, Umeå University, 90187 Umeå, Sweden 
a general societal level (a technology discourse) or at a school level (a school technology discourse). On the societal level, technology enjoys high status (Archer, Dawson, DeWitt, Seakins, and Wong 2015), but it has low priority among science-oriented subjects in Swedish primary and secondary education (e.g. Rasinen, Virtanen, Endepohls-Ulpe, Ikonen, Ebach and Stahl-von Zabern 2009). Swedish technology curricula are also vague and teachers put many different faces on the subject content (Rooke 2013). To speak in Basil Bernstein's terms (1975/2003), the subject of technology has weak classification and framing.

Different status connected to technology is also related to how it is gendered and classed. Men are thought to have a natural affinity with technology while women are presumed to fear or dislike technology (Bray 2007). Technology is seen as soaked by a masculinised culture where women have difficulty finding a place (e.g. Faulkner 2003). Ulf Mellström (2004) further points out how men, through their interactions and relationships with artefacts, create heterosexual gendered spaces where females are symbolically present since the interaction with the artefact often involves its feminisation. As a school subject, technology has been associated with boys experiencing school fatigue and their needs for practical applications (e.g. Layton 1995), although 'being practical', in a Swedish context, has traditionally been highly valued and tightly interconnected with 'being a man', specifically in rural areas, smaller towns and in working-class contexts (Mellström 1995).

Technical competence, Judy Wajcman (1991) argues, is central to the dominant cultural ideal of masculinity, and its absence is a key feature of stereotyped femininity. She points out the complex relationships between power, knowledge and technology and explains the links between technology and various forms of masculinity. On the one hand, technology may be linked to things associated with manual labour and machinery, such as dirt, noise and danger, which in turn are connected to notions of masculinity (such as physical strength and aggression). On the other hand, technology may be linked to analytical capacity that is also associated with notions about (another form of) masculinity, where obsession with computers and programming, for instance, may be a way for men who are social 'failures' to compensate for their lack of power. Mellström (1999) develops Wajcman's (1991) categorisation of various masculine identities in relation to technology and discusses their attitudes to and interest in the various forms of technology. Although they differ in how they approach the body, they are bound together by their common orientation towards technology. A 'mechanic' identity is characterised by practical handson work and often associated with the working-class masculinity, while the 'computer nerd' has a passionate but intellectualised approach to technology (see also Ottemo 2015).

So, although an overarching, technological discourse loads technology with high status, prestige and masculinity, it is paralleled by a school technology discourse which marginalises technology within school science, associating it with a kind of 'de-classed' (Gray and Kish-Gephart 2013) masculinity for theoretically weak students. Yet there are trends in Sweden reflecting a rising interest in programming skills in schools. For example, the Swedish National Agency for Education has, in a proposal to the government, formulated a new strategy for enhancing digital competence among students and teachers (Skolverket 2016). The Swedish Minister of Education, Gustav Fridolin, recently commented on it in the media, stating that "technical expertise in a modern society is a question of democracy" (Dagens Nyheter 2016-09-20).

The value of taking students outside of the classroom to participate in science-related activities not easily offered within the school building has long been recognised. There is also a substantial body of literature on this issue (Rennie 2014). For example, research has focused on visitors' learning outcomes and more recently also connected learning to visitors' interactions with each other, with the staff and different artefacts (Davidsson and 
Jakobsson 2012). However, only a few studies have linked informal science learning to issues of access, for example, to science centres, science museums, botanic gardens, and aquaria (Dawson 2014). Emily Dawson points to the risk that science centres and comparable institutions could become places that exclude students who belong to certain social categories, such as minority students and students whose parents lack higher education. However, according to Kathryn Scantlebury's review (2014) on gender issues in science education, an emerging research theme is now the need to provide under-represented groups space to engage with science outside the classroom.

Earlier studies in science education taking a power perspective have usually focused on the science classroom (e.g. Nyström 2007), and studies of science-oriented teaching in outside-of-school settings from such a perspective are less common. One exception is the study by Anton Puvirajah, Geeta Verma and Horace Webb (2012), which examines the mediation of power via context and language during a robotics competition in a more informal setting than the high school classroom. The authors find that the context influences how people talk to each other and thus also power relations among students and between teachers and students. In Puvirajah et al.'s study, science-oriented teaching in the classroom emerges as instrumental: this is where students learn things to get a grade and not because it has anything to do with life otherwise. Outside the classroom in a more authentic setting, power relations shift, and both teachers and students begin to ask more genuine questions surrounding scientific phenomena. Similar arguments in favour of what is called 'out-of-school science learning' (Rennie, Feher, Dierking and Falk 2003) also suggest the need to study how teaching in an out-of-school setting may contribute to challenging stereotyped power relations. Based on this research, I recognise that a contextual shift from the science classroom to a science centre involves a potential for students to engage in science/technology-specifically those who otherwise show disinterest in, or are limited by gendered and classed discourses of, these subjects. The aim of the article is therefore to explore and analyse whether and how stereotypical gendered power relations are negotiated and challenged when students programme Lego cars in the science centre. The research questions are:

- How do students engage in the tasks at the science centre?

- How do they talk about the tasks and their engagement?

\section{A school discourse}

In school, students do not only learn about science/technology and other school subjects. Earlier research shows that the school comes with its own discourses informing students about what's expected there, for example, routines and daily educational practices (Temple Adger and Wright 2015). Like all institutions, schools thus have "the power to foster particular kinds of identities to suit their own purposes" (Mayr 2015, p. 755). In school, students are constructed as female and male, and different expectations are inscribed on them. Tuula Gordon, Janet Holland and Elina Lahelma (2000), for example, highlight that girls in school are expected to be more still than boys, their bodies more contained and their voices quieter. While the movement of males is seen as natural, girls who use space extensively are more likely to be seen as behaving inappropriately: "[A girl's] movement is noticed more quickly, and commented on and controlled much more often" (Gordon 2006, p. 6). 
So, gendered notions about student behaviour in schools and classrooms form a school discourse that regulates students differently, depending on their sex. One effect of this school discourse, Victoria Foster (1996) argues, is the phenomenon of girls as caretakers of learning environments and of boys in the classroom:

For girls, the paradigm of caretaker is expressed in a constellation of required activities, for example, moderating the behaviour of boys, softening the classroom atmosphere, being "good girls", and not exhibiting the kinds of undisciplined behaviours which are taken to be "natural" for boys and which often gain sympathetic attention for them. By contrast, there is no similar expectation for boys to be carers or nurturers. (p. 195)

Foster further argues that (good) girls' expected caretaking gets intelligible within "the sexual contract". Within the sexual contract, the functions of caring, nurturance and emotional support are seen as women's functions (Foster 1996, p. 193). Foster's 'sexual contract' is, as I understand it, the equivalent of Judith Butler's 'heterosexual matrix', which I discuss in the next section.

\section{Gender as a 'doing', produced through the heterosexual matrix}

In this article I draw on Butler's (1990/1999) theories of gender as performative, a 'doing'. Gender is thereby understood as an effect rather than a cause. Butler explains that performativity resides in the repetition of discursive practices, that is, "the reiterative and citational practice by which discourse produces the effects that it names" (1993, p. 2). Also important for my understanding of gender performance is Butler's (1990/1999) explanation of gender as routinely produced through a 'heterosexual matrix' in which 'real' expressions of masculinity and femininity are embedded within a presupposed hegemonic heterosexuality:

I use the term heterosexual matrix ... to designate that grid of cultural intelligibility through which bodies, genders, and desires are naturalized ... a hegemonic discursive/epistemological model of gender intelligibility that assumes that for bodies to cohere and make sense there must be a stable sex expressed through a stable gender (masculine expresses male, feminine expresses female) that is oppositionally and hierarchically defined through the compulsory practice of heterosexuality. (note 6, p. 194)

Heterosexuality thus becomes the norm through which everything else is defined; a "normative force in the everyday construction of gender" that produces what comes to be recognised as natural expressions of femininity (Davies, Gonick, Gottschall, and Lampert 2013, p. 46). That is, 'doing gender' normatively means performing in an acceptable way in order to be recognised as intelligible in a particular situation and place, for example, while doing science/technology in the science classroom or at a science centre.

Butler draws on Michel Foucault when she argues that knowledge and power "work together to establish a set of subtle and explicit criteria for thinking the world" (2004, p. 215). This connects to Foucault's (1977/1991) thinking of power as relational and tightly interwoven with knowledge. According to Foucault (1971/1993), all practices have discursive aspects, which means that knowledge may be regarded as something that works through discursive practices in specific institutional settings, where it controls how others conduct themselves. Stuart Hall (2001) formulates this as follows: 
Just as the discourse 'rules in' certain ways of talking about a topic, defining an acceptable and intelligible way to talk, write, or conduct oneself, so also, by definition, it 'rules out', limits and restricts other ways of talking, of conducting ourselves in relation to the topic or constructing knowledge about it. (p. 72)

Following Hall (2001), I understand the power relations enacted at the science centre as depending on how the students and pedagogues, through their talk and practices, activate discourses that are available to them in this 'new' setting. Whether they are discourses of technology, school technology, programming, school, or other discourses connected to a specific science centre, those will influence how pedagogues and students 'do' gender in connection to the programming tasks. The science centre, therefore, cannot be seen as a 'neutral' place. While the masculine genderedness of science/technology/programming and the compulsion to 'do gender' normatively is strong due to the need to maintain the social recognition that acceptable performances of gender provide, it is important to trace the moments where the binary system of gender is disputed and challenged. As it happens, in the constant repetition, the re-performances of gender, there is space for rupture and change (Butler 2004).

\section{Methods}

\section{About the science centre}

The science centre that is the focus of this article is situated in a medium-sized city in the northern part of Sweden. According to their home page, the centre promotes science, technology and mathematics through a collaboration between the school administrations of the municipality and its neighbouring districts, the university and the local industry. The main purpose of the centre is to promote interest in science, technology and mathematics (Umevatoriet 2017) not least among girls (informal conversation with the pedagogues at the centre). The centre regularly receives school classes at all levels, and teaching is thematic and less traditional than ordinary classroom teaching.

\section{Study design}

In consultation with the science centre pedagogues who were familiar with the local schools and knew of teachers who might be interested in participating in the study, one school class (year 8) was selected as potential participants in the study and their teacher was contacted by e-mail. To protect students' anonymity, the name of the school is not given here. The theme at the centre for the school year 2014/2015, when the project was carried out, involved programming Lego cars. The school class spent one morning (2 h) at the centre. The science teacher added a lesson on programming in preparation for the visit to the centre.

Since the student visit lasted only $2 \mathrm{~h}$, I decided to use multiple camcorders to capture as many events in the classroom as possible and I visited the centre beforehand to test out the video equipment I had decided to use. I also wanted to ensure that the cameras were placed in the optimal locations (three cameras at different places in the room to capture as many students and their work as possible). The use of video in research is extensively discussed in methodological literature. For instance, Daniel Walsh, and colleagues (2007) highlight the video camera's capacity to record details that can reveal subtle differences in 
patterns of social interaction because it captures all events, not just those that are easy to notice. Furthermore, all parties' perspectives can be captured with the help of a camera, which leads to greater social justice with regard to representation in the data corpus (Davey 2010). This would appear to be important because, as Gordon, Holland, Lahelma, and Tarja Tolonen (2005) show, the gaze of the researcher easily orients toward movement and sounds, which often means noticing boys more than girls, thus resulting in gender bias. Several studies have also described weaknesses with video camera research. For example, there is always the risk of being fooled into thinking that everything is shown and nothing escapes the researchers' attention (Walsh et al. 2007). Therefore, as a complement to cameras, I also took notes in my diary. Three digital audio recorders were also placed on various desks to pick up student dialogue while the work was in progress. The desks were selected randomly.

After parents and students consented to participating in the research study, the class was observed during science lessons at school three times before the study visit to the centre in order to become more familiar with the students, and more importantly, for them to become familiar with me. I did this because I did not want students to focus on me when we got to the science centre. Instead, I wanted to be as 'invisible' to them as possible in order to avoid influencing the course of events during the study visit. Each lesson observation lasted $60 \mathrm{~min}$ and diary notes were taken. The notes concerned how the teacher approached the subject and students' engagement. Visiting the classroom provided me with a feeling of the school's science culture, which I found rather traditional.

After the study visit to the centre, I visited the class during another science lesson and I conducted four student interviews with a total of seven students (five girls and two boys). I interviewed all students who wanted to be interviewed. Video material recorded during the visit to the centre was used in one of the interviews. This interview did not take place until nine months after the visit to the science centre, when the class had already begun year 9 , while the three earlier interviews were held within 2 weeks of the visit. The reason for this 'late' interview was that this specific girl's behaviour in the science centre was identified as interesting for the analysis only after in-depth analysis of the video-recorded material had been done. All interviews were held in a small room next to the science classroom at the school. The semi-structured interviews lasted between 30 and $60 \mathrm{~min}$, and were recorded and transcribed verbatim. The interview questions concerned students' interests, perceptions of school science and school work more generally, the study visit at the science centre, technology and programming, and their future dreams.

\section{Working with video-data and interviews}

The analysis of the video material took place in several steps. However, I want to acknowledge that the steps were more 'messy' and overlapping than presented below, where they have been simplified in order to make the procedure easier to understand. First, I reviewed the videos from the three cameras individually to get an overview of the data. In the second step, I reviewed the videos again and found the times at which people or events filmed on one camera moved out of the frame and the continuation was picked up by another camera. This required quite a lot of piecing together, but in the process, I became very familiar with the video material and constantly discovered new details. I tabulated how student pairs collaborated, approached the teachers and used different artefacts, and how students moved and stayed in different places in the room. This approach helped me to see patterns but also special situations, some of which I had already noticed during my visit and some that were new to me. At this point, I had not decided which people or events I 
would follow particularly carefully; the process was more mechanical, although I took notes on things I found interesting. Third, I used Audio Premium Pro software (https:// www.udemy.com/adobe-premiere-pro/) to organise the clips so that an 'event', a pair or an individual could be followed more coherently along a time-line. Unfortunately, the sound from the digital audio recorders turned out to be of poor quality so I decided to not use the audio data. However, the video cameras took up sound quite well within a radius of approximately $1-1 \frac{1}{2} \mathrm{~m}$. Student conversations at the desks were nevertheless impossible to follow.

The videos, interviews and diary notes also served as 'sounding boards' to each other and a means of finding interesting events (noted in the diary and later found in the videos, or the reverse) or of getting students' explanations for things I had seen on the videos.

\section{Analytical work}

In my exploration of how students challenge and negotiate stereotypical gendered power relations at the science centre, I followed in the steps of Emma Renold and Jessica Ringrose (2008). In their work, Renold and Ringrose used Gilles Deleuze and Felix Guattari's (1987/2003) metaphor of 'molecularity' to point out their analytical focus in order to explore regulations and ruptures of tween and teenage girls' resistance to the heterosexual matrix:

Molecularity and 'molecular fluxes' offer a metaphor for looking at the minutiae through which discourse and power are reconstitutive in actions and talk, yet also malleable spaces of un-fixity. 'Imperceptibility' helps us to value the small and often passed over spaces where regulation and resistance might meet. (p. 320)

'Turning' to the details has also proven to be productive for my analytical work and I draw on Butler (2004), who highlights the importance of tracing the 'breaking points' where the binary system of gender is disputed and challenged. Butler writes:

[I]t will not be enough to isolate and identify the peculiar nexus of power and knowledge that gives rise to the field of intelligible things. Rather, it is necessary to track the way in which that field meets its breaking point, the moments of its discontinuities, and the sites where it fails to constitute the intelligibility it promises. What this means is that one looks for the conditions by which the object field is constituted as well as the limits of those conditions, the moment where they point up their contingency and their transformability. (pp. 215-216)

In practice, I concentrated on video clips where I could follow students more carefully. I looked through the video recordings and the interviews in parallel, back and forth several times in order to identify 'breaking points'; the 'small spaces' where students worked with or talked about the programming of Lego cars and simultaneously 'ruptured' normative discourses of femininity or masculinity (compare with Bronwyn Davies, Marnina Gonick, Kristina Gottschall, and Jo Lampert 2013). Like Davies et al. I then investigated whether these moments of ruptures were followed by 'recoups', i.e. if students returned to the normative rules of doing gender again. In line with what Margeret Wetherell, Stephanie Taylor, and SimeonYates (2001) suggest, I focused on how the students' talk and/or practices were organised, how it made sense, and created meaning. For instance, I asked questions about what the talk accomplished: "why this version or this utterances? What does it accomplish here and now?" (Taylor 2001, p. 17). 
An important implication for the analysis is, however, that it is not the subject but discourse that speaks and produces language and knowledge (Foucault 1982/1983; see also Butler's 1995 discussion about the subject that is constituted in, and within discourse). This is crucial because the principal interest of the research concern how knowledge and power are made by discourse and not what specific students 'say'. Foucault (1982/1983) uses 'subject' in two different senses, as pointed out by Hall (2001):

First, the discourse itself produces 'subjects' - figures who personify the particular forms of knowledge which the discourse produces. [-] These figures are specific to specific discursive regimes and historical periods. But the discourse also produces a place for the subject (i.e. the reader or viewer, who is also 'subjected to' discourse) from which its particular knowledge and meaning most makes sense. [-] All discourses, then, construct subject-positions, from which alone they make sense. (p. 80, original emphasis).

Thus subject can be seen both as personified discourse and as a position in discourse. However, as Davies and Rom Harré (2001) recognize, individuals are not only the bearers of knowledge produced by the discourse but are also capable of exercising choice in relation to discursive practices. Agency, according to Butler (1995) is to be found at "junctures where discourse is renewed." (p. 135). This opens up the possibilities of agency, or drawing on different discourses, or choosing different subject positions in different situations, thereby disrupting gendered borders.

\section{The study visit}

Two female science centre pedagogues, one accompanying teacher and the school class first gathered on the upper level of the centre in a room set up with rows of chairs. The lesson started with one of the pedagogues giving an introduction to the basics of working with the programming assignment. She also demonstrated some of the things the Lego car could do after programming.

Thereafter, we moved to the ground floor and a large space-about the size of two classrooms. There were no teachers' desks, blackboards or lab benches. The room was instead perceived as 'decorated' or ornamented by various creative inventions-more like a school art room than a place for science and technology. This is, according to the pedagogues, be simply because there is a very modest budget. The room was furnished with desks, each with seats for four people. At each desk, there was a laptop, a Lego car, a box of Lego materials and various types of connections and technical gadgets laid out for each pair (see Fig. 1). In addition to the desks, there was a large open area in the room and cube-shaped cushions that could work as a sofa along three of the walls.

The 20 students worked in pairs of which six were same sex. The pairs were the same as in the ordinary science lessons at their school, a decision made by their teacher. The two pedagogues circulated among the desks, answered questions and sometimes gave the students advice and suggestions for how they could proceed. I mainly moved between the three video cameras, but I sometimes moved closer to the students to watch what they were doing and listen to what they were talking about. I usually sat on one of the sofas when I took notes in my diary. I avoided talking to the students, although I sometimes asked them to explain what they were doing. 
Fig. 1 A Lego car on a box with Lego and technical gadgets

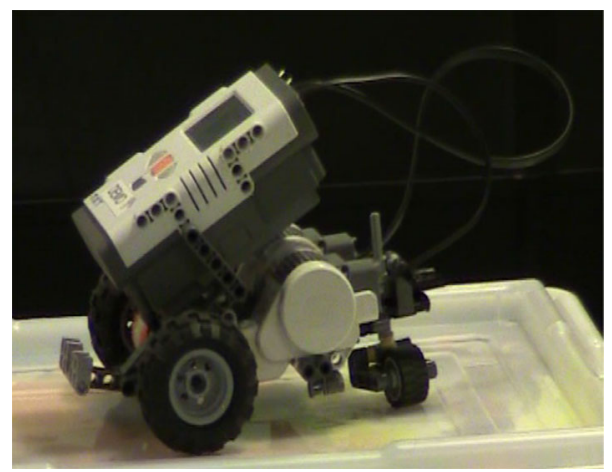

Before the students could begin to freely explore programming the Lego car, they had to complete two tasks to demonstrate that they had understood the basics of the programming: to make the car drive forward, stop and then reverse, and to make the car drive around in a circle. Once this was accomplished, the pedagogues laid out a plastic mat on the floor in the open area. Road designs were drawn on the mat, including a roundabout and different kinds of parking spaces (see Fig. 2). The idea was that it should be possible to programme the cars so that they would drive along the road, into the roundabout, or park-all depending on what the students wanted to try. The students also had access to several different kinds of sensors to build into their car so that it could, for example, differentiate between light and darkness, play a tune, or "say' various things, like "Hello" or "Have a nice day".

Towards the end of the morning, all students were assembled around the car mat, sitting on the cushions along the walls, and the pedagogues summed up the work the students had done, praised them and invited them to demonstrate to the others one of the things they had programmed the cars with. When the demonstration was over, the students went back to school with their teacher.

\section{Different layers of findings}

I present my findings and analysis as different 'layers' as a way to reflexively point out how challenging it was to actually see anything but stereotypical ways of doing gender and technology; to move beyond my own entrapment in binary categorisations (Stephenson

Fig. 2 The road designed mat

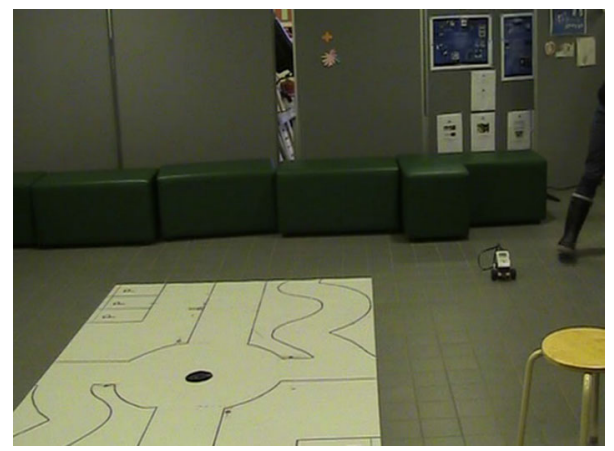


2011). In the following I start off by giving some examples of how students followed feminine and masculine norms at the science centre. Thereafter I turn to a more 'molecular reading' of students' work at the science centre and their talk about science, technology, and programming to show more complex patterns. I give examples from three student pairs (three girls and three boys) involved in these situations. Only the three girls wanted to participate in the interviews; and two of them were interviewed together. These student pairs were chosen since they, compared to each other, approached the tasks rather differently, and they were also captured rather well by the camera. They further constitute three different sexed groups (two girls, a girl and a boy, and two boys). The data show how students negotiate gender in relation to science/technology and programming, that is, how they come close to the discursive borders. The way they seem to 'talk themselves back' inside the discursive borders again is a sign of that. In the last section I combine a specific piece of video and interview data to show a 'performative surprise' (Butler 1990/1999, p. xxvi), an act which breaks with normative expectation (see also Renold and Ringrose 2008). This shows the potential for ruptures and change of the strong discursive borders surrounding gender and science/technology.

\section{A first impression}

My first impression of students' work at the science centre, which I noted in my diary, was that it followed traditionally gendered patterns. Those who seemed to be more familiar with programming were boys, and the girls seemed more anxious about doing things wrong. Some boys also took up a lot of space while most of the girls sat still and tried out the Lego car close to their own desk instead of moving out onto the mat. Many of the girls chose to attach a sensor to the Lego car while some boys rebuilt their Lego cars to, for example, attack vehicles. This 'first-impression' stereotypical pattern was also reinforced in that the pedagogues at the centre summarized the students' work at the end of class and congratulated the attack vehicle builders for "fantastic and creative work" and with soft voices said "ohhh" and "ahhh" when some girls showed how their Lego car could spin around and say "Have a nice day" (from diary 2014-10-10).

\section{Becoming intelligible within normative gender performances}

Susan and Sarah worked tightly together on the programming task. They sat so close to each other that they were nearly sharing the same chair. Now and then they even had their hands in tandem on the laptop keyboard. The two girls also worked quietly, and when they tested their Lego car they did it near their desk instead of stepping out to the more open space in the room. After a while, they seemed to lose interest in the task, but stayed at their desk and socialised with other girls nearby, or with Carl, one of the boys who kept turning up at their desk. Susan and Sarah did not seem to disturb anyone or to 'trouble' the pedagogues with questions.

One of the girls who kept moving back and forth between her own desk and that of Susan and Sarah's was Katarina. Katarina was supposed to work with Kenneth and for some time she stayed at their desk, although she did not engage in the programming. Instead, she supported him by passing him things from the Lego box when he asked for them, and although she followed him and carried the Lego car to the mat to try out what he had been programming, she became more and more passive with regards to the programming task. Instead, she balanced smoothly between relocating herself between the 
desks - depending on where in the room the pedagogues were positioned-keeping an eye on Kenneth so that she could follow him and carry the Lego car to the mat.

Kenneth, who worked hard with the programming, did not seem to care about Katarina's (dis)engagement. At a certain point, however, he left the computer and tried to engage in Carl's work instead. Carl, who from the beginning was working with Peter, had for some time shown frustration over being left by himself since Peter just walked away to another desk, where he stayed talking with some of the other students. Peter did not seem to have any problems leaving Carl to work on their joint programming task, instead he spent much time talking to other students. This happened even though it could not have escaped anyone that Carl loudly shouted for Peter to return and continue with their common assignment. The boys' performances did not prompt the pedagogues to act, either; it seems as if it was normal and expected behaviour.

My analysis of these first scenes is that the different student performances show how students are discursively, and differently, regulated by the school discourse concerning how to act in the classroom (Gordon 2006). To be seen as a 'good girl', a girl needs to regulate her voice and movements, something that is less likely to be expected from boys. Also, while technology is discursively coded as masculine it might appear to be natural, or at least expected, that girls have no interest in programming. So, as long as the girls stayed calm they somehow became invisible to the educators and could choose to perform as 'disinterested' subjects. That is, doing 'disinterest' in the science classroom is also a way to do femininity and thus, as girls, to become intelligible.

\section{Negotiating gender}

In this section, I return to Carl and his attempts to get Peter to return to the joint assignment. As noted above, Carl was doing masculinity by shouting and allowing himself to verbally occupy space at the centre. However, looking more closely at how he calls out for Peter, it renders him as helpless and a bit clingy, in need of his close friend, and as somewhat fragile being left alone; things stereotypically associated with femininity. For instance, Carl shouts: “Aren't you supposed to work with your team-mate? You are just roaming around! Peter! Why are you leaving all the time?" Carl's frustration was also evident when he chided Kenneth, who had gradually become less interested in his own Lego car and more interested in Carl's project: "This is Peter's and my car!" as if to emphasise with whom he actually wanted to work. Carl's transgression from doing masculinity to performing more stereotypically feminine 'helplessness' or 'I-need-you-to-behere' talk can be read as an ongoing negotiation of gender. Carl further commutes between this helplessness and more masculine performances when he acts and plays with a Lego figure, which he calls 'she' and 'the girl'. He informs Kenneth that he is going to run over 'the girl', and he places the Lego car on the floor and releases the car, which runs over the Lego figure. When Carl exclaims: "So fucking cool! Peter! Peter, I fixed the drive-by!" Peter comes up to Carl, who says: "It works now! Set up the girl. Get ready!" He continues to demonstrate, and calls out to another student: "Lucas! You have to see his drive-by!" Lucas and two other boys join to watch, and when the car runs over the Lego figure, everyone laughs.

My interpretation is that Carl, by showing his longing for Peter's company, is 'bumping' into the discursive border of doing masculinity 'correctly'. He nearly ruptures the border and therefore needs to normalise, and even strengthen, his masculinity again. He does this through his gender-oppressive play with a 'passive' feminised and inferior Lego figure, and an 'active' masculinised Lego car. I believe this is a moment when normative 
discourses of masculinity are ruptured but then recouped back to the gender norms again (compare with Davies et al. 2013).

A similar rupture of borders followed by a recoup is also seen in the dialogue between Susan and Sarah, the girls who worked tightly together with the programming task from the start but soon seemed to lose interest. In the interview a couple of weeks after the visit to the science centre, Susan first describes the programming as rather boring, although she simultaneously opens up to the idea that the task could have been fun if it had been less easy and more cool:

Susan: It was boring, 'cause we didn't do anything... any cool thing. We just made it [the car] go back and forth and spin and then it said something.

Sarah: It would have been more fun if there had been more stuff to do, like build our own robot.

Eva (interviewer): So why did you go there? What was the purpose?

Susan: To learn programming.

Eva: Is that important?

Susan: Yes it is. That's something you need to know. For example, if you buy a TV, you need to know how to programme it and things like that, computers, your mobile phone and stuff like that. The world is becoming more and more electronic, you know, and you need to know how to programme stuff. Or... if you want to become a programmer.

Eva: Are you interested in that? Programming?

Sarah: No.

Susan: My dad is very good at stuff like that.

Here Susan and Sarah negotiate around how to represent themselves in relation to technology and programming. First, they talk rather enthusiastically about the need to learn programming, which they also think could be fun if they had more interesting things to work with. This statement is in line with their eagerness to engage in the programming task, which they did at the beginning of the class, although in a 'school girly' way of friendly sharing of both chair and laptop keyboard. I think their discursive practice and talk about the task points to a discursive opening to enjoying programming and simultaneously doing femininity, that is, a rupture of borders. Notwithstanding, as the interview goes on, they distance themselves again. Although there is this brief moment of rupturing the gendered norm of programming when Susan involves the possibility of being willing to become a programmer ["Or... if you want to become a programmer"], the dialogue immediately shifts back and it becomes clear that programming is not an option. Sarah also underlines this in concluding that they are not interested in programming. The final comment on Susan's father being good at programming adds to their rhetorical work in distancing themselves from programming thus reinstating it as a masculine practice.

\section{A performative surprise}

Here I return to Katarina and Kenneth, the pair where he worked with the programming while she faded into passivity. After several viewings of the video data I saw something that had escaped me earlier, probably because I was more focused on Kenneth's action than on Katarina's passivity. What I saw was that Katarina, after Kenneth had left her, started to work on her own with the computer. She also engaged her teacher and one of the boys more successful in programming in helping her out. To me, this was a surprise, not because I didn't think Katarina was able to programme but because of her earlier passivity. 
The surprise was in that she moved from performing passivity to showing much agency. It seems that her potential and will to learn was hampered by working with Kenneth. When I later interviewed Katarina and asked why Kenneth did all the programming, she explained this labour division, and justified it, as an effect of Kenneth's programming skills, and she even took responsibility by saying that she should have been more serious about demanding access.

Katarina I think he thought he could do more than me and then it became like he had to decide... yes. I told him several times that [laughing] I wanted to do something as well.

Eva Yes. He took over?

Katarina He took over [both of us laughing] Simply...

Eva Yes.

1 -1

Katarina But I... and I tried several times with: "Can't we do it like in this way?" but "Wait I'm just testing," he said... and then.

Eva Mmm.

Katarina He said: "I just want to try one more thing" [sighing].

1-1

Katarina He has a pretty strong will, so... That's why... And... so... I think he wanted... he thought it was fun and he wanted to try his stuff.

Eva Yes.

Katarina And then maybe he thought, "Oh, she cannot do anything, so I'll try for myself." [Laughing]. But... I don't think it could have been done in any other way. Eva No?

Katarina'Cause in the end I still got to test [programming].

Eva Mmm.

Katarina Maybe I could have said a little earlier that I wanted us to work together. Eva Mmm.

Katarina But otherwise... I don't actually think...

1-1

Katarina But in the end... In the end I learned more how to do it. But still... it did not work very well.

Eva Yes.

Katarina But. It was still exciting.

Eva But when you say...

Katarina Interesting.

Eva Yes.

Katarina When I understood it, you know. It was like a little robot you got to [programme].

In the interview Katarina positions herself as wanting to participate in the programming and she gives different explanations to why it didn't happen, although she says that she tried to get access (he thought he was better skilled; he wanted to try some more things; he has a strong will; he thought it was fun). She (and also I) laughs several times during the interview-it seems so easy for Kenneth to keep going and make Katarina sit by passively, in line with the active/passive divide between men and women. However, when Kenneth left Katarina on her own, she was no longer restricted by the active/passive division between them, and she could challenge the gendered notions that girls are not supposed to be interested in programming. Thereby Katarina 'succeeded' in both performing femininity 
within a heteronormative discourse and then challenging it. As Butler (2004) argues, in the re-performances of gender there is space for rupture and change, and for 'performative surprises' (Butler 1990).

\section{Discussion}

In this article I explore and analyse whether and how stereotypical gendered power relations are negotiated and challenged when students programme Lego cars in a science centre. I found that traditional gender stereotypical patterns still exist when students work with or talk about science/technology. My interpretation is that the school discourse regulates students differently, depending on their sex. This is seen in how they use the space, move around, and how they speak. This is for example seen in Sarah and Susan's modest and prudent work and Carl's shouting on Peter concerning where and with whom to work with. Such different expectations are, according to Gordon et al. (2000), seen as 'natural' and not often questioned in a school context. The school discourse thereby creates differently gendered subject positions (Hall 2001) for girls and boys when they work at the science centre.

The school discourse is further activated together with a technology discourse, which connect technology to masculinity (Wajcman 1991), through students and teachers talk and practices. The examples I give in this article of how students do gender stereotypically, show also how the heterosexual matrix (Butler 1990/1999) regulates their work. This is, for example, seen in how Katarina, working with Kenneth, is held back in her wish to try out programming. Her disengagement with the computer, which continues until Kenneth leaves her and their Lego car, becomes intelligible within a presupposed hegemonic heterosexuality where she becomes a passive and he an active subject. However, also in the interview, Katarina's talk witnesses about how the school discourse, the technology discourse and discourses about heterosexuality come together and produce knowledge (Foucault 1971/1993) that 'explains' their labour division practice so that it becomes intelligible.

Although the discourses define acceptable ways for students to conduct themselves (Hall 2001), the analysis also shows that both girls and boys negotiate, move close to, and challenge stereotypically gendered borders. It is in the contradictory spaces within and between 'new' and older discourses that negotiated 'identity work' is most clearly seen (Walkerdine 1991). And, Sue Jackson, Tiina Vares and Rosalind Gill (2012) write: "Relevant to such negotiation are the notions of complicity and resistance; power may both constrain and enable" (p. 148). This is for instance seen when Carl at one moment is involved in doing femininity - that is when he expresses a kind of helplessness and longing for Peter-but in next moment doing masculinity while playing a gender oppressive game.

The sudden ruptures point to the situated-ness of gender performances and how power is both productive and relational (Foucault 1977/1991). In this study I find that the fluidity of gender and students' negotiations of norms are mostly situated in micro events; in the 'molecularity' (Deleuze and Guattari 1987/2003) and therefore difficult to see, even though these events were video-taped and systematically worked with. That does not mean that they are irrelevant —on the contrary-it shows that students have (at least some) agency to negotiate and challenge gendered norms and boundaries-also when they are in a science/ technology context. I have showed that the 'ruptures' (Renold and Ringrose 2008) of the norm, the doing gender differently, applies both to girls and boys at the science centre. The 
regulation of the gender is however strong since a rupture often is followed by a 'recoup' (Davies et al. 2013). Important in the analysis is therefore also to carefully listen to students' talk from the interviews, and what it accomplish (Wetherell 2001). The recoups in the interview situation with Susan and Sarah is, for example, seen in the rhetorical work (Wetherell et al. 2001) these students need to do to after rupturing the gendered norm of programming.

According Butler (1995) agency is to be found in the junctures where discourse is renewed. Therefore, I find it important to trace breaking points in students' discursive practices and talk. One question is, however, whether it might be a possibility for us as researchers and teachers to also organize, encourage and speed up "malleable spaces of unfixity" (Renold and Ringrose 2008, p. 320) to come.

The results of this study, and my own struggle to explore and analyse, demonstrate how difficult it must be for pedagogues and teachers to grasp what is happening in the moment, understand why it is happening and then come up with ideas about what to change in order to make school science/technology more inclusive for all students. However, I have some thoughts that I would like to share. One thing that struck me was that it is good to remember that students, when they leave the science classroom and enter a science centre, come with already quite established gender and power relations and gendered notions about school science/technology. Therefore, it is necessary to carefully think through what one wants to do and how. For example, consideration should be given to how such a visit is to be organised, not just the specific tasks but also the actual space. It could also be a good idea to reflect on the tasks which students are going to collaborate on. There must also be clear directions so that students have a fair chance to collaborate on equal terms. Open areas need to be complemented by other 'rooms' in order to allow students to try out different things without being judged by others. More generally, I believe that it is important for teachers and researchers to work together and develop learning situations that make it possible to investigate how subject positions are created, and what voices or interests that benefit from a particular problem-solving situation. Such an approach to learning would give teachers, and students, better tools to see, discuss, and challenge stereotypical norms and notions of gender and science/technology.

I will end this article by acknowledging that there are different ways to interpret what happens in the described situations, and I do not believe there is a 'true' story, or "an independent order of reality" (Taylor 2001, p. 319). However, I draw on criteria such as transparency regarding my methods and analytical work, and reflexivity concerning the overall research process as a way to allow for my work to be evaluated (Taylor 2001).

Acknowledgements Funding was provided by Teacher Education, Umeå University.

Open Access This article is distributed under the terms of the Creative Commons Attribution 4.0 International License (http://creativecommons.org/licenses/by/4.0/), which permits unrestricted use, distribution, and reproduction in any medium, provided you give appropriate credit to the original author(s) and the source, provide a link to the Creative Commons license, and indicate if changes were made.

\section{References}

Archer, L., Dawson, E., DeWitt, J., Seakins, A., \& Wong, B. (2015). "Science capital": A conceptual, methodological, and empirical argument for extending Bourdieusian notions of capital beyond the arts. Journal of Research in Science Teaching, 52(7), 922-948. https://doi.org/10.1002/tea.21227. 
Bernstein, B. (1975/2003). Class, codes and control. Towards a theory of educational transmission (Vol. 3). London: Routledge.

Bray, F. (2007). Gender and technology. Annual Review of Anthropology, 36, 37-53. https://doi.org/10. 1146/annurev.anthro.36.081406.094328.

Butler, J. (1990/1999). Gender trouble. London: Routledge.

Butler, J. (1993). Bodies that matter. London: Routledge.

Butler, J. (1995). For a careful reading. In S. Benhabib, J. Butler, D. Cornell, \& N. Fraser (Eds.), Feminist contentions. A philosophical exchange (pp. 127-143). London: Routledge.

Butler, J. (2004). Undoing gender. London: Routledge.

Davey, G. (2010). Visual ethnography-SWAT. Visual Anthropology, 23, 344-352.

Davidsson, E., \& Jakobsson, A. (2012). Understanding interactions at science centers and museums. Approaching sociocultural perspectives. Rotterdam: Sense Publishers.

Davies, B., Gonick, M., Gottschall, K., \& Lampert, J. (2013). Ruptures in the heterosexual matrix through teenage flows and mulitiplicities. Girlhood Studies, 6(1), 46-62. https://doi.org/10.3167/ghs.2013. 060105.

Davies, B., \& Harré, R. (2001). Positioning: The discursive production of selves. In M. Wetherell, S. Taylor, \& S. J. Yates (Eds.), Discourse theory and practice. A reader (pp. 261-271). London: Sage.

Dawson, E. (2014). Equity in informal science education: Developing an access and equity framework for science museums and science centres. Studies in Science Education, 50(2), 209-247. https://doi.org/10. 1080/03057267.2014.957558.

Deleuze, G., \& Guattari, F. (1987/2003). A thousand plateaus. Capitalism \& schizophrenia. London: Continuum.

Faulkner, W. (2003). Teknikfrågan i feminismen [The technology question in feminism]. In B. Berner (Ed.), Vem tillhör tekniken? [Who owns the technology?] (pp. 23-52). Arkiv förlag: Lund.

Foster, V. (1996). Space invaders: Desire and threat in the schooling of girls. The High School Journal, 79(3), 191-201. http://www.jstor.org/stable/40364717.

Foucault, M. (1971/1993). Diskursens ordning. [The discourse order]. Stockholm/Stehag: Brutus Östlings Bokförlag.

Foucault, M. (1977/1991). Discipline and punish. The birth of the prison. London: Penguin Books.

Foucault, M. (1982/1983). The subject and power. In H. Dreyfus, \& P. Rabinow (Eds.), Beyond structuralism and hermeneutics (pp. 208-226). Brighton: Harvester.

Gordon, T. (2006). Girls in education: Citizenship, agency and emotions. Gender and Education, 18(1), 1-15. https://doi.org/10.1080/09540250500194880.

Gordon, T., Holland, J., \& Lahelma, E. (2000). Making spaces: Citizenship and difference in schools. New York: St. Martin's Press.

Gordon, T., Holland, J., Lahelma, E., \& Tolonen, T. (2005). Gazing with intent: Ethnographic practice in classrooms. Qualitative Research, 5(1), 113-131. https://doi.org/10.1177/14687941105048659.

Gray, B., \& Kish-Gephart, J. J. (2013). Encountering social class differences at work: How "class work" perpetuates inequality. Academy of Management Review, 38, 670-699.

Hall, S. (2001). Foucault: Power, knowledge and discourse. In M. Wetherell, S. Taylor, \& S. J. Yates (Eds.), Discourse theory and practice. A reader (pp. 72-81). London: Sage.

Jackson, S., Vares, T., \& Gill, R. (2012). The whole playboy mansion image: Girls' fashioning and fashioned selves within a postfeminist culture. Feminism \& Psychology, 23(2), 143-162. https://doi.org/10. $1177 / 0959$.

Layton, D. (1995). Constructing and reconstructing school technology in England and Wales. International Journal of Technology and Design Education, 5, 89-118.

Mayr, A. (2015). Institutional discourse. In D. Tannen, H. E. Hamilton, \& D. Chiffrin (Eds.), The handbook of discourse analysis (2nd ed., pp. 755-774). Wiley: Blackwell.

Mellström, U. (1995). Engineering lives: Technology, time and space in a male-centred world, Dissertation, Lund's University, Lund.

Mellström, U. (1999). Män och deras maskiner [The men and their machines]. Nora: Nya Doxa.

Mellström, U. (2004). Machines and masculine subjectivity. Technology as an integral part of men's life experiences. Men and Masculinities, 6(4), 368-382. https://doi.org/10.1177/1097184X03260960.

Nyström, E. (2007). Talking and taking positions. An encounter between action research and the gendered and racialised discourses of school science, Dissertation, Umeå University, Umeå.

Ottemo, A. (2015). Kön, kropp, begär och teknik. Passion och instrumentalitet på två tekniska högskoleprogram. [Gender, body, desire, and technology: Passion and instrumentality in two technical university programs], Dissertation, Göteborgs universitet. Doktorsavhandling, Göteborg. 
Puvirajah, A., Verma, G., \& Webb, H. (2012). Examining the mediation of power in a collaborative community: Engaging in informal science as authentic practice. Cultural Studies of Science Education, 7, 375-408. https://doi.org/10.1007/s11422-012-9394-2.

Rasinen, A., Virtanen, S., Endepohls-Ulpe, M., Ikonen, P., Ebach, J., \& Stahl-von Zabern, J. (2009). Technology education for children in primary schools in Finland and Germany: Different school systems, similar problems and how to overcome them. International Journal of Technology and Design Education, 19, 367-379. https://doi.org/10.1007/s10798-009-9097-5.

Rennie, L. J. (2014). Learning science outside of school. In N. G. Lederman \& S. K. Abell (Eds.), Handbook of research on science education (Vol. 2, pp. 120-144). New York: Routledge.

Rennie, L. J., Feher, E., Dierking, L. D., \& Falk, J. H. (2003). Toward an agenda for advancing research on science learning in out of school settings. Journal of Research in Science Teaching, 40(2), 112-120. https://doi.org/10.1002/tea.10067.

Renold, E., \& Ringrose, J. (2008). Regulation and rupture. Mapping the tween and teenage girls' resistance to the heterosexual matrix. Feminist Theory, 9(3), 313-338. https://doi.org/10.1177/ 1464700108095854.

Rooke, G. (2013). In search for gender awareness in technology education. Stockholm: KTH Institute of Technology, Licentiatavhandling.

Scantlebury, K. (2014). Gender matters. Building on the past, recognizing the present, and looking toward the future. In N. G. Lederman \& S. K. Abell (Eds.), Handbook of research on science education (Vol. 2, pp. 187-203). New York: Routledge.

Skolverket [Swedish National Agency for Education]. (2016). Nationell strategi för digitaliseringen av skolväsendet avseende förskolan, förskoleklassen, fritidshemmet samt den obligatoriska skolan. http:// www.skolverket.se/om-skolverket/publikationer/visa-enskild-publikation?_xurl_http\%3A\%2F\% 2Fwww5.skolverket.se\%2Fwtpub\%2Fws\%2Fskolbok\%2Fwpubext\%2Ftrycksak\%2FBlob\% 2Fpdf3621.pdf\%3Fk\%3D3621.

Stephenson, A. (2011). Can we be wolves? Intersections between Deleuze's difference and repetition and Butler's performativity. In R. Faber \& A. Stephenson (Eds.), Secrets of becoming: Negotiating Whitehead, Deleuze and Butler (pp. 92-107). New York: Fordham University Press.

Taylor, S. (2001). Evaluating and applying discourse analytical research. In M. Wetherell, S. Taylor, \& S. J. Yates (Eds.), Discourse as data. A guide for analysis (pp. 311-330). London: Sage.

Temple Adger, C., \& Wright, L. J. (2015). Discourse in educational settings. In D. Tannen, H. E. Hamilton, \& D. Chiffrin (Eds.), The handbook of discourse analysis (2nd ed., pp. 857-879). Oxford: Wiley Blackwell.

Umevatoriet. (2017). http://www.umevatoriet.se/?page_id=17\&lang=en.

Wajcman, J. (1991). Feminism confronts technology. Cambridge: Polity Press.

Walkerdine, V. (1991). Schoolgirl fictions. London: Verso.

Walsh, D. J., Bakir, N., Lee, T. B., Chung, Y., et al. (2007). Using digital video in field-based research with children. In A. J. Hatch (Ed.), Early childhood qualitative research (pp. 43-62). New York: Routledge Haudrup.

Wetherell, M. (2001). Themes in discourse research: The case of Diana. In M. Wetherell, S. Taylor, \& S. J. Yates (Eds.), Discourse theory and practice. A reader (pp. 14-28). London: Sage.

Wetherell, M., Taylor, S., \& Yates, S. J. (Eds.). (2001). Discourse theory and practice. A reader. London: Sage.

Eva Silfver is associate professor at the Department of Education, Umeå University. One of her research interests focuses on how gendered (and other) notions in are reproduced in science education and how research and practice can come together and challenge norms. 